This is an open access article under the terms of the CC-BY 3.0 License.

Peer review method: Double-Blind

Date of acceptance: September 16, 2020

Date of publication: November 11, 2020

Review article

DOI: https://www.doi.org/10.47305/JLIA2060055p

\title{
THE WORLD HEALTH ORGANIZATION: \\ THE COVID-19 PANDEMIC AND TRANSNATIONAL LAW
}

\author{
Carla Piffer \\ University of Vale do Itajaí (UNIVALI), Brazil \\ ORCID iD: https://orcid.org/0000-0002-1294-7248 \\ carlapiffer@univali.br \\ Paulo Márcio Cruz \\ Universityof Vale do Itajaí (UNIVALI), Brazil \\ ORCID iD: https://orcid.org/0000-0002-3361-2041 \\ pcruz@univali.br
}

\begin{abstract}
The reflections made in this writing, bring to discussion the importance of transnational law, in the face of the occurrence of the current pandemic. From this, considerations are made about the transnational law produced by the WHO against Covid-19. Also, an analysis is made of the central categories and their relationship with the prefix 'trans-' and transnational law. Subsequently, the WHO is discussed, its emergence and performance in the elaboration of a transnational legal framework to be considered when internalizing its guidelines by each Member State. In the context of final considerations, it is emphasized, in addition to the importance that should be attributed to transnational law that the work of the WHO, as a transnational actor, practices materialized acts such as transnational law, both in terms of guidance and in connection with public health matters. The methodology used was based on the inductive method, using the bibliographic research.
\end{abstract}

Keywords: Coronavirus; Pandemic; Transnational law; World Health Organization; Transnationality

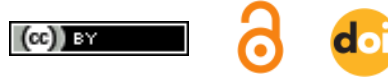




\section{INTRODUCTION}

The novel coronavirus disease (COVID-19) has rapidly spread worldwide. It gained a pandemic status, and is currently affecting, without distinction, the most (and the least) important world powers. We are facing a global public health crisis with unprecedented economic effects. Actually, we fear something that, in fact, cannot be seen. Faced with a context of uncertainties, the goal of the present study was to discuss the importance of transnational law in view of the occurrence of transnational phenomena - such as the current COVID-19 pandemic - analyzing the transnational law to be applied by states, based on the guidelines provided by the World Health Organization (WHO) for managing COVID-19. Initially, we address the categories 'endemic', 'epidemic', and 'pandemic' to determine the connection between the prefixes 'pan-' and 'trans-', and the relationship with transnational law.

Subsequently, we present a brief outline on the emergence of the WHO and its performance in the elaboration of a transnational legal framework to be taken into consideration by each Member State when implementing the WHO guidelines.

The methodology used was based on the inductive method, using the reference, category and operational concepts techniques, and bibliographic research.

\section{A REFLECTION ON THE CATEGORIES}

Since infectious diseases began to have endemic, epidemic, or pandemic characteristics, the bases for combating them started to have fundamentally transnational characteristics from the second half of modernity. Especially from the beginning of the XX century, at a time when many cases of infectious diseases began to be registered in the control systems of official health agencies, these facts started to gain visibility through the media, which began to report on the existence of endemics, epidemics, and the consequent risk of pandemics. In the case of the present study, it was important to establish the concepts of each of these categories.

These diseases, in some cases, are endemic, i.e., when a certain number of cases occurs historically in a specific region. When this endemic level is overcome, that is, when there is an increase in the historical case curve, it is correct to affirm that there is an outbreak or epidemic. However, the distinction between epidemic and endemic (Rezende 1998, 154) cannot be made based only on the greater or lesser incidence of a certain disease on a population. What defines the endemic character of a disease is the fact that it is the same for a population, country, or region (Rezende 1998, 153).

A pandemic outbreak of a disease, incorporated into the medical glossary from the XVIII century (Rezende 1998) onwards, being an epidemic of worldwide proportions, is characterized by the emergence of cases in several countries from different continents. 
The term 'pandemic', originating from the neutral prefix 'pan-', which indicates the idea of everything, entirely, and 'demos' (people) was used for the first time by Plato, in his book Laws- XI (Platão 1999). This way, it is possible to link the prefix 'pan-' to the prefix 'trans-', suggesting the existence of a certain issue, occurrence, or phenomenon between and beyond countries. They are different; however, if we consider that pandemic, as in the case of the present study, indicates the occurrence of cases in numerous places (i.e. deterritorialization), it becomes a transnational phenomenon. Consequently, it should prompt a transnational action, i.e. the two prefixes are complementary, especially when it comes to 'cause' (pan-) and 'effect/reaction' (trans-).

\section{The World Health Organization and Its Transnational Character}

Since the XIX century, numerous attempts have been made in order to create institutionalized mechanisms for providing technical cooperation, especially among the European powers at that time. Throughout the XX century, specifically in the periods after the great wars and the Cold War, the world witnessed the flourishing of several reorganized or formally created international organizations or bodies. The subjects of their constitutive treaties began to outline the deliberation of common global agendas, involving topics on security, world peace, economy, work, free trade, environment, and health, among many others. The engagement of efforts in favor of common interests, enhanced by major world episodes, such as the great wars and the end of the Cold War, has demonstrated and demonstrates the central core of the creation and functioning/maintenance of international organizations.

Specifically, regarding health, several attempts have been made since the XIX century to organize an international institution for addressing world health problems. It is true that there are disagreements with respect to the reasons for the emergence of forums and international cooperation bodies for achieving consensus concerning health and strategic actions for the control and prevention of diseases. However, there is also consensus on the fundamental factor that justifies the creation of this organism, i.e., the growing flow of goods and individuals - which results from the industrialization and the expansion of markets in urban centers - and its relationship with the increase in diseases (Lima 2002). Thus, the World Health Organization (WHO) was created in 1946, governed by the Constitution of the World Health Organization, in force since April $7^{\text {th }} 1948$ (Godlee 1994). Its preamble asserts that: "The Member States of this Constitution declare, in accordance with the Charter of the United Nations, that the following principles are fundamental for the happiness, harmonious relations, and security of all peoples (...)" (WHO 1946). Currently, composed of 194 states, as a member of the United Nations (UN) system, it is one of the most decentralized organizations in the family, entrusting its six regional offices (Africa, the Americas, Southeast Asia, Europe, the Eastern Mediterranean, and the Western Pacific) the formulation of guidelines for the 
respective regions, as well as the execution of the decisions of the headquarters, located in Geneva, Switzerland (Biehl and Petryna 2013). In addition to its vast geographical scope, the WHO occupies a unique position in global health, thanks to its visionary official charter - called the Constitution, which is unusual in the UN system - ensuring a social approach to health, and affirming it as a human right (Legge 2012). The human rights discourse was the tool used by the WHO to face the usual restrictions of diplomacy of the states (Biehl and Petryna 2013,3) although much remains to be done in this regard. In this context, the UN, through its organizations such as the International Labor Organization (ILO), the World Trade Organization (WTO), and the WHO, for example, is essentially of transnational character. It provides regulations and guidelines that are internalized by the Member States, which, since decades, began to create a framework of legal rules of transnational nature.

Transnational Law and the World Health Organization

Addressing transnational law means referring to the classic work of American diplomat, scholar and jurist Philip C. Jessup, dating from 1956. Just over a decade after the end of World War II, and experiencing a unique historical moment of improvement and intensification of relations between states, this author was emphatic in affirming that the states are not the only group that interests us, and that the term 'international' is misleading, since it suggests that we concern ourselves only with the relationships between a nation (or state) and other nations (or states) (Jessup 1965). Other authors, such as Vagts, Steiner and Koh (Steiner and Vagts1976; Vagts 1986; Koh 1996) also followed Jessup's trend, evolving the analysis of the topic gradually, as the world society itself started to face transnational demands, occurrences, and legal issues.

With the development of globalization, transnationality, as a phenomenon, started to be observed in a hyaline way. It was highlighted as manifestations of transnationality (Piffer and Cruz 2018) or transnationality as a reflective phenomenon of globalization. New manifestations of globalization, different forms of belonging to socio-cultural and political arrangements (Ribeiro 1997,3) deterritorialization (Stelzer $2009,25)$, difficulty in relating the phenomenon to a given territory reconfiguration of cultural identities, and new social and economic agents, among other factors, demonstrate that the edge has already crossed national borders.

At this point, it is worth recalling the five points of convergence that demonstrate some of the main characteristic features of transnational relationships that compose transnationality, namely: horizontal relationships; constant and influential relationships; disruption of the state unit; network of legalities; and weakening of control and social protection systems. As a result, the more the phenomenon is consolidated, the more evident is the need to accept the existence of transnational law. 
This mechanism has a unique feature, i.e. the untying of the production of autonomous political norms in a fragmented world society, as pointed out by Teubner (2003). Instead of the hierarchy and unity of Law in the constitutional state, attention is drawn to the heterarchical plurality of legal orders, among them those produced by international organizations (Teubner 2009; Teubner 2005).

Still, according to Teubner (2010, 331-332), supra- and transnational orders (public and private) bring elements of complexity to the legal systems. This way, already pacified assumptions of modernity should necessarily be reread. The evaluation of Law in globalization proposes the existence of a diversity of 'global civil constitutions', in specific sectoral spheres, often outside the policy exercised by the states, therefore treated in a wrong way by the classic division between public international law and private international law.

In this way, transnational law does not emanate from a single 'will-forming' center, but is produced by a multiplicity of simultaneous decisions, which, according to Teubner, should be called 'polycentric law' (Teubner 2010). Therefore, it is no longer possible to understand such concepts in their classic versions if they are still operational concepts to describe this institutional experience (Morais 2011, 12). Consequently, new power and competition relations have been observed, and new factors of incompatibility between the social agents and the state units started to be put to the test on a daily basis, making Law adapt to the new events (Piffer and Cruz 2020, 35) because Law is a social fact or phenomenon; it does not exist without society, and cannot be conceived outside of it (Reale 2002).

This pluralism of legal orders involves state and non-state agents beyond the limits of the states that are not fully able to conduct official international legal acts, given that legal reflexes of transnational relations are not limited to economic issues. Litigation involving human rights - and consequently health-related issues environmental issues, transnational governance acts, transnational social organizations, labor relations, family relations, public or private contracts, and many other legal and non-legal areas compose the current transnational legal pluralism (Piffer and Cruz 2020, 40).

Specifically, with regard to the role of the WHO as a transnational agent, an ongoing debate involves two factors, namely: 1) whether this international body should be predominantly a normative agency, setting standards, developing protocols, and providing information that can be used by governments and agencies when implementing their programs; or 2) the extent to which it should be involved in implementing its own programs (McCarthy, 2002). The answer to this question should be given taking into account the phenomenon of transnationality and the plurality of agents inserted in unique socio-political and legal contexts. It is worth mentioning that, in both cases, the WHO plays the role of transnational agent and contributes to the production of health-related transnational law. 
The characteristics of transnational agent relating to this organization are evidenced by standardizing health actions and policies worldwide, offering guideline and protocol manuals, advising member countries on the execution of health policies and programs, implementing actions, intervening in the fight against diseases and inequalities that affect the health status of populations, preparing global health reports, and defining their implementation by the health systems of the Member States. The production of transnational law in this area becomes evident at the moment when the Member States produce their internal regulations based on guidelines issued by the WHO.

The goal of the present study is in line with one of the binding documents produced within the scope of the WHO, known as International Health Regulations (IHR). ${ }^{1}$ This document was prepared by all Member States and established rules to be applied by countries in order to stop the spread of epidemics. In $2005{ }^{2}$ this regulation was extended by including new diseases to the list of the 1995 IHR.

As a demonstration of the transnational aspect of the topic, the IHR included new concepts and categories that re-dimensioned international disease control, establishing an approach that covers all possible risks, regardless of their source or origin. It established the terminology 'Public Health Emergency of International Concern' (PHEIC), and made Member States responsible for notifying the WHO about "all events in their territories that might constitute a PHEIC" (Fidler 2005, 362). In addition, it is worth noting that the issues addressed in the IHR have been constantly discussed in order to adapt them to the current world reality.

As a way of internalizing the referred document, Brazil started to adapt the existing national structures and resources to meet the requirements of basic issues - in accordance with the IHR - such as those related to surveillance activities, reports, notifications, verification, response, and collaboration in the activities involved in each topic included in the regulation. This fact was demonstrated by the Ministry of Health 2016 National Focal Point Operation Plan for the 2016 IHR (Brazil 2016). Likewise, similar action was expected from the others Member States. The importance of the performance of a transnational agent and the elaboration of a transnational legal framework on health today is justified given the occurrence of a PHEIC. The projection of articulated actions involving the Member States promoted by the WHO demonstrates the need for engagement of the entire planet in the face of the occurrence of the coronavirus pandemic, an issue that will be addressed next.

\footnotetext{
${ }^{1}$ The International Health Regulations (IHR) is a binding international legal instrument for 196 countries worldwide, which includes all Member States of the World Health Organization (WHO). Its goal is to help the international community prevent and respond to serious public health risks that have the potential to cross borders and threaten people around the world.

2 The IHR came into effect on 15 June, 2007. At that time, all MERCOSUR countries had already ratified these regulations.
} 
The $15^{\text {th }}$ edition of the Global Risk Report presented at the World Economic Forum, in Davos, Switzerland, which took place in January 2020, indicated that health systems were under new pressures around the world in the face of vulnerabilities resulting from changing social, environmental, demographic, and technological practices and habits. Indeed, this is more than an accurate finding. With the recent declaration of the COVID-19 pandemic by the WHO, two months after the referred report, the issues addressed in it were fully confirmed. According to the statement by the WHO Director-General, Tedros Adhanom Ghebreyesus:

We are all affected by the growing COVID-19 pandemic. It is an unprecedented health challenge and we know that people and organizations everywhere want to help. The World Health Organization (WHO) is leading and coordinating the global effort, supporting countries to prevent, detect, and respond to the pandemic (WHO 2020).

If we go back to the characteristics of the transnationality phenomenon, we will realize that a pandemic - like the one occurring today - can be described as an infectious disease that spreads among populations located in extensive geographic regions, for example, a continent, or even the planet Earth, in a transnational manner. As with many phenomena of transnational scope (migration, environment-related issues, crime, economics, etc.), the current COVID-19 pandemic knows no borders, does not respect sovereign states, or world economic powers, and does not differentiate between races or social classes; it simply crosses the territorial boundaries established after the Westphalia Treaty. In addition, it pierces, frightens, and causes the most feared damage, the materialization of the risk of risks, i.e. the loss of thousands and thousands of lives.

Furthermore Miglino (2007) stated that the ecological problem would probably lead to the creation of transnational power centers, going beyond the ideology and legal structure of international relations. However, many scholars disagreed. Today, the question is: Who will disagree with the need of transnational power centers targeted at maintaining life? It is difficult to find a more consistent argument than this one.

However, as a response to the current COVID-19 pandemic, states began to close in on themselves, restricting their territorially - in a non-uniform and unplanned manner - without taking into consideration any possibility of global cooperation in favor of the most essential common interest, i.e. the maintenance of life. The principle of solidarity in the face of common axiological guidelines, materialized by cooperation, and invoked so many times in the international arena, has always seemed inadequate, not to say unnecessary. It is worth mentioning that the same effect might be related to transnational law. 
In a recent study on the current pandemic, Ferrajoli (2020) pointed out to the "(...) dramatic confirmation of the need and urgency of achieving a planetary constitutionalism (...)". This author also mentions the need for effective and homogeneous measures to be adopted targeted at preventing the variety of procedures performed - in many cases completely inadequate - from favoring infection and multiplying the damage for everybody.

In the case of Europe, the whole legal apparatus involving European law and the divergent measures adopted by the countries of the European Union (and by its former member, the United Kingdom) go against any basic cooperation, world interdependence, global community, or the fact that global problems are transnational challenges and demand global responses.

The sense of transnational law, "applied by institutions with bodies and organizations for governance, regulation, intervention (...)" (Cruz and Oliviero 2012, 22) and the joint action of the transnational bodies and organizations become feasible and indispensable in the face of the current facts. From the establishment of transnational public spaces, the existing transnational health law, within the scope of the WHO, becomes the instrument for guiding transnational powers, with the intensification of the processes of abdicating the sovereign powers of states (Cruz and Oliviero 2012, 22).

Currently, more than before, there is a call for recognition and respect for a world society affected, without distinction, by challenges arising from transnational phenomena - to which the current COVID-19 pandemic is now added. At this moment, we cannot forget Beck's teachings regarding the dependence relations between national states - as territorial states with their power founded on the link with a given space and world society, given that it relativizes and interferes in the performance of those states, "(...) because an immense variety of connected places cross their territorial borders, establishing new social circles, communication networks, market relations, and forms of coexistence (...)" (Beck 1999, 18). Transnational law, applied by states based on the WHO guidelines against COVID-19, together with the establishment of urgent planetary action guided by transnational networks of cooperation and solidarity, offers effectiveness and efficiency to new global transnational governance strategies targeted at controlling and combating the current COVID-19 pandemic. Therefore, this global society affected by transnational problems requires the consolidation of transnational law, initially produced by the WHO guidelines, and oriented by cooperation in solidarity actions. The world market and large transnational companies know that they are able to produce and distribute medical equipment and health materials. Countries that may be less affected, or better prepared to deal with the current pandemic, could send health professionals to those most in need. The global economy, guided by its important agents, could create adequate economic policies, thus contributing to mitigate the economic damage caused, and avoiding numerous social problems. This way, it would be possible to establish the transnational public spaces that society needs. 


\section{CONCLUSION}

The goal of the present study, conducted in the midst of the COVID-19 pandemic, was to emphasize the importance of transnational law in the face of a transnational phenomenon of this nature, with proportions that cannot yet be estimated, and with all due respect to international law, as we already know that this is a step forward. This perspective means no longer Law between states, but Law created from transactional issues by the states.

Using the classification of 'pandemic' instead of 'endemic' opens the possibility and, above all, denotes the need of coordinated and joint application of the WHO guidelines by its Member States, under the form of transnational law to be internalized individually against COVID-19.

It is worth noting that the $\mathrm{WHO}$, issuing protocols, recommendations, and standards in the face of a pandemic, allows the states, under the same basis of guidance, to edit their own internal rules and materialize the transnational law that will guide and link public health actions.

It is evident that this transnational law, created from the scope of a transnational agent, should also be permeated by transnational networks of cooperation and solidarity. This fact will make it possible to provide the due degree of efficiency to global strategies, recognizing the fact that we are dealing with nothing more and nothing less than the preservation of life on a planetary scale. 


\section{REFERENCES}

1. Beck, Ulrich. 1999. O que é globalização? Equívocos do globalismo. Respostas à globalização.São Paulo: Paz e Terra.

2. Biehl, João, andPetryna, Adriana. 2013. "Critical global health".In When people come first - critical studies in global health, edited by JoãoBiehl, AdrianaPetryna, 01-22. Princeton: Princeton University Press.

3. BrazilianMinistryof Health. 2016. "Plano de Operação do Ponto Focal Nacional para o Regulamento Sanitário Internacional". Accessed March 20, 2020. http://bvsms.saude.gov.br/bvs/publicacoes/plano_operacao_ponto_focal_naciona I_regulamento_sanitario_internacional.pdf.

4. Cruz, Paulo M., andOliviero, Maurizio. 2012."Reflexões sobre o direito transnacional". Revista NovosEstudos Jurídicos, April. Accessed February 25, 2020. https://siaiap32.univali.br/seer/index.php/nej/article/view/3635/2178.

5. Ferrajoli, Luigi.2020.// virus mette la globalizzazione con i piedi per terra. Accessed March 22, 2020. https://ilmanifesto.it/il-virus-mette-la-globalizzazione-con-ipiedi-per-terra/.

6. Fidler, David P. 2005. "From International Sanitary Conventions to Global Health Security: TheNew International Health Regulations". Chinese Journal of International Law, September. Accessed March 22, 2020.https://academic.oup.com/chinesejil/article/4/2/325/490058.

7. Godlee, Fiona. 1994. "The World Health Organization: WHO in crisis". BMJ British MedicalJournal, November. Accessed March 20, 2020.https://www.bmj.com/content/309/6966/1424.abstract.

8. Jessup, Philip. 1965. Direitotransnacional. São Paulo: Fundo de Cultura.

9. Koh, Harold H. 1996. "Transnational Legal Process". Faculty Scholarship Series. Paper 2096.New Haven: Yale Law School. Accessed October 12, 2019. http://digitalcommons.law.yale.edu/fss_papers/2096.

10. Legge, David. 2012. "Future of WHO hangs in the balance". BMJ - British Medical Journal, October. Accessed March 18, 2020. https://www.bmj.com/content/345/bmj.e6877.full.

11. Lima, Nísia T. 2002. "O Brasil e a Organização Pan-Americana da Saúde: uma história em trêsdimensões". In Caminhos da Saúde Pública no Brasil, editedbyFinkelman, J. Rio de Janeiro: Fiocruz.

12. McCarthy, Michael. 2002. "What's going on at the World Health Organization?" The Lancet, 360: 1108-10. Accessed March 20, 2020. https://www.thelancet.com/action/showPdf?pii=S0140-6736\%2802\%2911243-8.

13. Miglino, Arnaldo.2007."Unacomunitámondiale per la tuteladell'ambiente". ArchivioGiuridico, IV: 563-79- 2007. MucchiEditore: Modena. 
14. Morais, José Luiz B. de. 2011. As crises do Estado e da Constituição e a transformação espaço-temporal dos direitos humanos. Porto Alegre: Livraria do Advogado.

15. Piffer, Carla and Cruz, Paulo M.2018. "Manifestações do Direito Transnacional e daTransnacionalidade". In Transnacionalidade e sustentabilidade: dificuldades e possibilidades em um mundo em transformação, editedby Carla Piffer, Paulo M. Cruz, Guilherme R. Baldan, 8-27. Porto Velho: EMERON. https://emeron.tjro.jus.br/images/noticias/2018/04/Ebook_transnacionalidadeSustentabilidade.pdf.

16. Piffer, Carla and Cruz, Paulo. M. 2020."O direito transnacional e a consolidação de um pluralismo jurídico transnacional". In Interfaces entre direito $e$ transnacionalidade, editedby Heloise S. Garcia, Paulo M. Cruz, 29-42.Itajaí: AICTS.Accessed March 22, 2020. https://www.univali.br/vida-no-campus/editoraunivali/ebooks/Documents/ecjs/Ebook\%20\%202020\%20\%20INTERFACES\%20ENTRE\%20D IREITO\%20E\%20TRANSNACIONALIDADE.pdf.

17. Platão. As leis. 1999. Translated by Edson Bini. Bauru: Edipro, 1999.

18. Reale, Miguel. 2020. Lições Preliminares de Direito. São Paulo: Saraiva.

19. Rezende, Joffre M. de. 1998."Epidemia, endemia, pandemia. Epidemiologia". Revista dePatologia Tropica/27: 153-55. Accessed March 22, 2020. https://www.revistas.ufg.br/iptsp/article/view/17199/10371.

20. Ribeiro, Gustavo L. 1997. A condição da transnacionalidade. Brasília: Universidade de Brasília.

21. Steiner, Henry. J. andVagts,Detlev F. 1976. Transnational Legal Problems. Materials and Text. New York: The Foundation Press.

22. Stelzer, Joana. 2009. "O fenômeno da transnacionalização da dimensão jurídica". In Direito e Transnacionalidade, editedby : Paulo M. Cruz, Joana Stelzer, 24-43. Curitiba, Juruá.

23. Teubner, Gunther. 2003. "A Bukowina Global sobre a Emergência de um Pluralismo JurídicoTransnacional". Impulso 14:9-32.

24. Teubner, Gunther. 2005. El derecho como sistema autopoiético de la sociedad global. Lima, Peru:ARA Editores.

25. Teubner, Gunther. 2009. "The Corporate Codes of Multinationals: Company Constitutions BeyondCorporate Governance and Co-determination". In Conflict of laws and laws of conflict in Europe and beyond: patterns of supranational and transnational juridification, edited by R. Nickei, 1-10. Oxford: Hart.

26. Teubner, Gunther. 2010. "Fragmented Foundations: Societal Constitutionalism Beyond the NationState". In The Twilight of Constitutionalism?,edited by P. Dobner, M. Loughlin, 331-354. Oxford: Oxford University Press. 
27. Vagts, Detlev. F. 1986. Transnational business problems. New York: The Foundation Press.

28. WHO - World Health Organization. 1946. "Constitution of the World Health Organization".Accessed March 18, 2020.

http://www.direitoshumanos.usp.br/index.php/OMS-

Organiza\%C3\%A7\%C3\%A3o-Mundial-da-Sa\%C3\%BAde/constituicao-da- worldhealth-organization-omswho.html.

29. WHO - World Health Organization. 2020. "La OMS, la Fundación pro NacionesUnidas y susasociadosponen en marcha el Fondode Respuesta Solidaria a la COVID-19, primera iniciativa en su género".Accessed 20 March, 2020. https://www.who.int/es/news-room/detail/13-03-2020-who-un-foundation-andpartners-launch-first-of-its-kind-COVID-19 -solidarity-response-fund. 